BENJAMIN SUTER

\title{
THE CONTRA PROFERENTEM RULE IN THE REPORTS OF THE WAITANGI TRIBUNAL
}

\author{
LLM RESEARCH PAPER
}

LAWS 547: THE WAITANGI TRIBUNAL AND NEW ZEALAND LEGAL HISTORY

\section{FACULTY OF LAW}

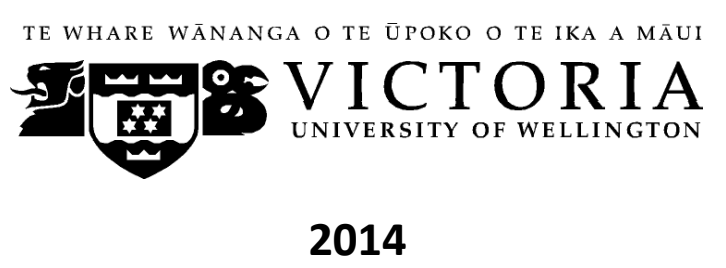




\section{Table of Contents}

I. Introduction $\quad 4$

II. The contra proferentem rule in Treaties with Native Americans 5

III. The adoption of the contra proferentem rule by the Waitangi Tribunal 6

$\begin{array}{ll}\text { IV. Historic background } & \mathbf{7}\end{array}$

A. $\quad$ Drafting of the Treaty by Europeans $\quad 7$

B. Deliberations among Mãori Chiefs 9

C. Signing of the Treaty by Māori Chiefs 9

V. The application of the contra proferentem rule by the Waitangi Tribunal 10

A. A survey of the reports of the Waitangi Tribunal 10

B. Analysis of the application of the contra proferentem rule by the Waitangi Tribunal 18

1. The different methods of applying the rule 18

$\begin{array}{ll}\text { a) Coordinated application } & 18\end{array}$

b) Precedence of the Māori text 18

c) Application sensu stricto 19

d) Contextualised interpretation 19

2. The misconceived significance of the Māori text 10

VI. The Treaty and Māori oral culture $\quad 21$

$\begin{array}{lr}\text { VII. Conclusions } & 26\end{array}$ 


\section{Abstract}

This paper examines the Waitangi Tribunal's application of the contra proferentem rule, a rule developed by United States courts for the interpretation of treaties with Native Americans. The Waitangi Tribunal adopted the Unites States courts' approach in one of its earliest reports when interpreting the Treaty of Waitangi and has held on to it ever since, even though it is less prominent in the later reports. As a survey of Tribunal reports reveals, the Tribunal has used the contra proferentem rule to different effects. A comparison of the circumstances surrounding the treaties with Native Americans in the United States and the signing of the Treaty of Waitangi however reveals crucial differences that make an interpretation of the Treaty contra proferentem inappropriate. Given that the Treaty is essentially the text in the Māori language, this paper argues, it should be interpreted as a Māori document, that is to say in the Mãori oral and cultural context of the Treaty signings. This however is something that the Tribunal only very rarely attempts.

\section{Word length}

The text of this paper (excluding abstract, table of contents, footnotes and bibliography) comprises 7,267 words.

\section{Subjects and Topics}

eg.

Treaty of Waitangi Tribunal

Contra proferentem rule Māori text. 


\section{Introduction}

Established in 1975, the Waitangi Tribunal has been assigned the task to determine the meaning and effect of the Treaty of Waitangi as embodied in the two texts. Facing the significant differences between the Māori and the English text of the Treaty, the Tribunal had to find ways to align the two versions.

In order to achieve this, the Tribunal relies partly on what it refers to as the contra proferentem rule: an approach developed first by courts in the United States, stating that treaties with American Indians must be construed in the sense in which they would naturally be understood by the Indians.

The Tribunal's approach of interpreting the Treaty contra proferentem was the subject of a historical debate. Giselle Byrnes criticised the Tribunal, arguing the Tribunal was required to examine both texts but, instead of doing that, applied the contra proferentem rule. ${ }^{1}$ Byrnes' criticism was rejected by Jim McAloon who argued that the Tribunal was taking an entirely orthodox approach founded on an eminently orthodox British text ${ }^{2}$ and could therefore not be accused of exceeding its powers. ${ }^{3}$

This was by and large a debate on the legality of the Tribunal's application of the contra proferentem rule under the Treaty of Waitangi Act. This paper will not enter into said debate. Instead, this paper will examine the application of the rule in historical terms, that is in view of the history of the Treaty of Waitangi.

This paper will assess the Tribunal's application of the contra proferentem rule against the historic background of the drafting and debating of the Treaty. First, this paper will look at whether the assumptions made by the United States courts hold true for the signing of the Treaty at the meeting of Waitangi. This will require a brief account of the history of the Treaty of Waitangi. Then, the paper will analyse the different ways in which the Tribunal has applied the contra proferentem rule in its reports. Last, it will

\footnotetext{
${ }^{1}$ Giselle Byrnes The Waitangi Tribunal and New Zealand history (Oxford University Press, Melbourne, 2004) at $132-133$.

${ }^{2}$ Arnold Duncan McNair The Law of Treaties (Clarendon, Oxford, 1961).

${ }^{3}$ Jim McAloon "By Which Standards? History and the Waitangi Tribunal" (2006) 40 NZJH 194 at 197.
} 
examine whether the Tribunal's method of ascertaining the content of the Treaty may be criticised from a historical perspective.

\section{The contra proferentem rule in Treaties with Native Americans}

In the $19^{\text {th }}$ century, courts in the United States faced the task of interpreting treaties concluded between the United States and American Indian tribes. In the 1832 case of Worcester v Georgia the United States Supreme Court expressed serious doubts as to whether it could reasonably be assumed that the Indians were aware of the differences in the legal meaning of some of the words used in the treaty. ${ }^{4}$ In the 1899 case of Jones $v$ Meehan, the United States Supreme Court established a general rule of interpreting treaties with Indian tribes: ${ }^{5}$

In construing any Treaty between the United States and an Indian tribe, it must always ... be borne in mind that the negotiations for the Treaty are conducted, on the part of the United States, an enlightened and powerful nation, by representatives skilled in diplomacy, masters of a written language, understanding the modes and forms of creating the various technical estates known to their law, and assisted by an interpreter employed by themselves; that the Treaty is drawn up by them and in their own language; that the Indians, on the other hand, are a weak and dependent people, who have no written language and are wholly unfamiliar with all the forms of legal expression, and whose only knowledge of the terms in which the Treaty is framed is that imparted to them by the interpreter employed by the United States, and that the Treaty must therefore be construed, not according to the technical meaning of its words to learned lawyers, but in the sense in which they would naturally be understood by the Indians.

The Canadian courts have adopted similar rules of interpretation. The British Columbia Court of Appeal held in the 1964 decision in $R v$ White, referring to the United States case Worcester $v$ State of Georgia ${ }^{6}$ : "The language used in treaties with the Indians should never be construed to their prejudice." 7 In the 1981 case of $R v$ Taylor, the Ontario Court of Appeal found, making reference to $R v$ White: ${ }^{8}$

${ }^{4}$ Worcester $v$ State of Georgia [1832] 31 US 515 at 552.

${ }^{5}$ Jones $v$ Meehan [1899] 175 US 1 at 5.

${ }^{6}$ Worcester $v$ State of Georgia, above $\mathrm{n} 4$.

${ }^{7} R v$ White [1964] CarswellBC 212 (BC CA) at [125].

${ }^{8} R$ v Taylor [1981] CarswellOnt 641 (Ont CA) at [19]. 
Further, if there is any ambiguity in the words or phrases used, not only should the words be interpreted as against the framers or drafters of such treaties, but such language should not be interpreted or construed to the prejudice of the Indians if another construction is reasonably possible ...

The native population of North America prior to Columbus' arrival in 1492 has never been precisely determined. Recent estimates range between eight and eighteen million Indians. ${ }^{9}$ At the time, Native North Americans spoke more than 400 languages, which belonged to some 62 language families. ${ }^{10}$

The United States concluded around 600 treaties with American Indians. ${ }^{11}$ Most, if not all of them, ${ }^{12}$ were negotiated and written not in the Native language but in English, ${ }^{13}$ which is hardly surprising given the enormous linguistic diversity that was found in North America.

With rare exceptions, the treaties followed a formal European form, with separate articles for each subject and "always much legalistic language", as some authors put it. ${ }^{14}$

\section{The adoption of the contra proferentem rule by the Waitangi Tribunal}

The Tribunal, drawing on a submission of the Department of Māori Affairs, adopted the United States courts' approach first in the Motunui-Waitara Report. ${ }^{15}$ The approach was regarded as an extension of the rule of contra proferentem, pursuant to which an

\footnotetext{
${ }^{9}$ Mark Q Sutton An Introduction to Native North America (Allyn and Bacon, Boston, 1999) at 7.

${ }^{10}$ Ives Goddard "Introduction" in Ives Goddard (ed) Handbook of North American Indians (Smithsonian Institution, Washington, 1996) 1 at 4-8 (Table 3); Sutton, above $n$ 9, at 8.

${ }^{11}$ Arthur Spirling "US Treaty Making with American Indians: Institutional Change and Relative Power, 1784-1911” 56 AJPS 84 at 85.

${ }^{12}$ At least there appears to be no record of treaties drawn up in a Native language.

${ }^{13}$ Bruce E Johansen Enduring Legacies: Native American Treaties and Contemporary Controversies (Praeger, Westport, Conn, 2004) at xiv.

${ }^{14}$ Vine Deloria and Raymond J DeMallie Documents of American Indian diplomacy (University of Oklahoma Press, Norman, 1999) at 11.

${ }^{15}$ Waitangi Tribunal Motunui-Waitara Report (Wai 6, 1983) at 49.
} 
ambiguous provision should be construed against the party that drafted or proposed the provision. $^{16}$

The Tribunal considered the issue in more detail in the Orakei Report, where it conceded that the circumstances mentioned in Jones $v$ Meehan were "not in all respects similar to those surrounding the signing of the Treaty of Waitangi by the Māori signatories". ${ }^{17}$ Nevertheless, it found there were sufficient similarities as to hold on to the approach: Few, if any, of the Māori chiefs were able to read English and not all of them could read Māori. Only the Māori text was relevant for them. ${ }^{18}$ The Tribunal also quoted from the Canadian case $R v$ Taylor $^{19}$.

The dissimilarities referred to by the Tribunal will be examined below, which however requires first setting out the history of the Treaty.

\section{Historic background}

\section{A. Drafting of the Treaty by Europeans}

The history of the Treaty can be said to have begun in the early 1830s, when Māori appealed twice to the British Crown: once in 1830, after British subjects had taken part in a violent raid on the South Island, and once in 1831, after the arrival of a French warship had instigated fear of French intentions to annex New Zealand. ${ }^{20}$ The Crown's reaction was to appoint James Busby as Resident in 1832 to ensure the protection of the Māori and the better control of British subjects. ${ }^{21}$

Busby had on his appointment been instructed by Richard Bourke, the Governor of New South Wales, to direct the Māori people "towards a settled form of government and ... some system of jurisprudence". 22

\footnotetext{
${ }^{16}$ At 49 .

${ }^{17}$ Waitangi Tribunal Orakei Report (Wai 9, 1987) at 128.

${ }^{18}$ At 128.

${ }^{19} R v$ Taylor, above $\mathrm{n} 8$.

${ }^{20}$ Claudia Orange The Treaty of Waitangi (2nd ed, Bridget Williams Books, Wellington, 2011) at 21.

${ }^{21}$ At 22.

${ }^{22}$ At 28.
} 
In the late $1830 \mathrm{~s}$, British conviction grew that an intervention in New Zealand was necessary: In particular, three European accounts called for a British response: a petition from European settlers and traders following a serious outbreak of tribal fighting; a report from Busby on the "miserable condition" of the Māori people that was caused partly by European impact; and another report from naval captain William Hobson suggesting to set up some sort of British trade factories. ${ }^{23}$ After a period of vacillation, the British Colonial Office concluded in 1839 that British colonisation of New Zealand was inevitable, which justified British intervention despite its prior official recognition of New Zealand's independence in $1836 .{ }^{24}$ Hobson was assigned the task to secure sovereignty for Britain, by treaty if possible.

By the end of January 1840, invitations for an assembly on 5 February 1840 were sent out in the name of Busby to Māori chiefs. ${ }^{25}$ Shortly before the meeting, Hobson started drawing up a draft treaty. Hobson's notes were delivered to Busby who then finished the draft treaty in English. ${ }^{26}$ The English draft was presented on 4 February 1840 to Henry Williams, a Church Missionary Society member, for translation into Māori. Together with his son Edward, Williams performed the task. ${ }^{27}$ While the exact wording of the draft given to Williams remains unknown, ${ }^{28}$ it is generally assumed that Williams' translation was rather inaccurate. ${ }^{29}$ Given the lack of Māori assistance in translating the $\mathrm{draft}^{30}$ it is not surprising that the language of the translation was not indigenous Māori but “missionary Māori, specifically Protestant missionary Māori”. 31

\footnotetext{
${ }^{23}$ At 32-33.

${ }^{24}$ At $36-38$.

${ }^{25}$ At 43 .

${ }^{26}$ At 44 .

${ }^{27}$ At 46.

${ }^{28}$ At 46; Ruth Ross "Te Tiriti o Waitangi: Texts and Translations" (1972) 6 NZJH 129 at 133.

${ }^{29}$ See Orange, above n 20, at 47-49; Ross, above n 28, at 139-153; Byrnes, above n 1, at 33-34; Michael Belgrave Historical frictions (Auckland University Press, Auckland, 2005) at 49-50.

${ }^{30}$ Orange, above $\mathrm{n} 20$, at 46.

${ }^{31}$ Ross, above n 28, at 136.
} 


\section{B. Deliberations among Māori Chiefs}

The meeting of Waitangi began in the morning of 5 February 1840. After stating briefly to the Europeans the purpose of the meeting, Hobson addressed the chiefs (with Williams translating), explaining to them the Crown's motivation to offer the Treaty. ${ }^{32}$ Hobson finished in reading the English text of the Treaty, after which Williams read the Māori text. $^{33}$

Then Busby spoke to the assembly on the matter of land, stating that the Governor would return all lands unjustly acquired from them - a promise that Hobson reaffirmed when the debate on the Treaty began. ${ }^{34}$ The chiefs debated the Treaty for about five hours, following the customary procedure of whaikorero (formal speeches) and debate. ${ }^{35}$ The meeting was brought to a close in late afternoon, but the Treaty continued to be discussed in the evening among Māori. ${ }^{36}$ By the morning of 6 February 1840, the chiefs had decided to immediately conclude the business. ${ }^{37}$

\section{Signing of the Treaty by Māori Chiefs}

Hobson opened the meeting of 6 February 1840. The Treaty in Māori language lay on the table ready to be signed. ${ }^{38}$ After two interruptions by the French missionary Bishop Jean Baptiste François Pompallier and the English missionary printer William Colenso, who questioned the Māori's awareness of their legal position according to the Treaty, the signing of the Treaty began. ${ }^{39}$ On that day, between 42 and 52 Māori chiefs signed the Treaty. ${ }^{40}$

Over the course of the next seven months, about 500 additional signatures were obtained. While Hobson shortly after the signing at Waitangi visited many chiefs in order

\footnotetext{
${ }^{32}$ Orange, above n 20, at 51-52.

${ }^{33}$ At 52.

${ }^{34}$ At 52-53.

${ }^{35}$ At 53.

36 At 56.

${ }^{37}$ At 57.

${ }^{38}$ At 58.

${ }^{39}$ At 58-60.

${ }^{40}$ At 60, 71 and 272.
} 
to secure further signatures, ${ }^{41}$ in March several missionaries were appointed to be official negotiators and given Treaty copies signed by Hobson. ${ }^{42}$ All in all, nine Treaty copies were signed throughout the country by between five (Waikato sheet) and 240 chiefs (Waitangi sheet). ${ }^{43}$ Altogether, they carried more than 500 signatures. ${ }^{44}$ On two occasions only, in March or April 1840 at Waikato Heads and on 26 April 1840 at Manukau, did some chiefs sign the English text of the Treaty (32 or 33 at Waikato and six or seven at Manukau). ${ }^{45}$ All the other chiefs signed the Māori text. ${ }^{46}$

The reasons why the chiefs at Waikato Heads and Manukau signed the English text are not clear. ${ }^{47}$ It appears that the local missionary, Robert Maunsell, only received an English version: There is no evidence of a copy of the Māori text being present at the time of the signing. ${ }^{48}$ Neither is there record that any explanation of the Treaty was given. $^{49}$

\section{The application of the contra proferentem rule by the Waitangi Tribunal}

\section{A. The misconceived significance of the Māori text}

As stated above, the Tribunal has conceded that the circumstances in North America were "not in all respects similar to those surrounding the signing of the Treaty of Waitangi by the Māori signatories" in New Zealand. ${ }^{50}$ Of these dissimilarities, one particular stands out:

\footnotetext{
41 At 64-69.

42 At 72 .

43 At $70-71$.

${ }^{44}$ At 272.

${ }^{45}$ Waitangi Tribunal, above n 15, at 47 (33 and six); Orange, above n 20, at 71 (32 and seven).

${ }^{46}$ Waitangi Tribunal, above $\mathrm{n} 15$, at 47.

47 At 47.

${ }^{48}$ Ross, above n 28, at 136.

${ }^{49}$ Orange, above n 20, at 73.

${ }^{50}$ See above III.
} 
The vast majority of signatures on the Māori text compared to the English text suggest that the Māori text, if any, ${ }^{51}$ should be regarded as the authoritative version. This argument was first made by historian Ruth Ross in $1972,{ }^{52}$ and has been repeated many times ever since. ${ }^{53}$

The argument is supported by the distinct treatment of the two texts: The Māori text was signed by both sides, the overwhelming majority of Māori chiefs and Governor Hobson. In contrast, the English text was signed by Hobson and a small minority of Māori chiefs, and possibly only by accident. Perhaps tellingly, when Hobson sent copies of the Treaty texts to the Secretary of State, the Māori text was entitled "Treaty" and the English text "Translation". ${ }^{54}$ Earlier, a copy of the English version had been dispatched with an-obviously incorrect-certification by Williams that "the above is as literal a translation of the Treaty of Waitangi as the idiom of language will admit of.",55

The point made by Ross receives much of its weight by the differences between the two texts of the Treaty. As has been seen above, the Māori text was written as a translation of an English draft - of a draft however that has not survived. A comparison of the two texts that have come to be regarded as official (the Māori text signed by most of the chiefs and the English text signed by some chiefs at Waikato Heads and Manukau) reveals many important discrepancies. ${ }^{56}$ The discrepancies are of such a nature that made Bruce Biggs ask whether the two texts are "in any reasonable sense equivalent", ${ }^{57}$ that is whether they can in fact be regarded as translations. For Biggs the answer "has to be "no"". 58 Similarly, the Tribunal held: 59

\footnotetext{
51 The importance of the oral and cultural context of the Treaty signings will be dealt with below: see VI.

52 See Ross, above n 28, at 136.

${ }^{53}$ Belgrave, above n 29, at 52.

${ }^{54}$ Ross, above n 28, at 134, n 31(e).

55 Orange, above n 20, at 86; Ross, above n 28, at 135.

56 See Bruce Biggs "Humpty-Dumpty and the Treaty of Waitangi" in IH Kawharu (ed) Waitangi: Māori and Pākehā Perspectives of the Treaty of Waitangi (Oxford University Press, Auckland, 1989) 300.

${ }^{57}$ At 310.

${ }^{58}$ At 310.

${ }^{59}$ Waitangi Tribunal, above n 15, at 46.
} 
In a consideration of the specific terms of the Treaty it is important to appreciate that the Māori text is not a translation of the English text and conversely, nor is the English version a translation of the Māori.

In this author's opinion, the significance of this argument has not been fully recognized. Rather, in the Motunui-Waitara Report the Waitangi Tribunal—undoubtedly led by the task assigned to it by Parliament "to determine the meaning and effect of the Treaty as embodied in the 2 texts" ${ }^{\prime 60}$-endorsed the view that both texts must apply. ${ }^{61}$ It declared that it inclined to the "'European' legal approach to the interpretation of treaties", notably concerning the interpretation of bilingual treaties and the rule of contra proferentem. ${ }^{62}$ In the Manukau Report it confirmed to apply "the rules affecting bilingual treaties". ${ }^{63}$ It also reiterated its intention to have regard to the contra proferentem rule as applied by United States courts when interpreting treaties with American Indian tribes. ${ }^{64}$

The United States Supreme Court's rationale is based on the fact that the Indian tribes entered into treaties that were drawn up not in their own language but in English. They were thus written in a language that had over centuries developed legal terms with a clear technical meaning. The argument rests on the assumption that the Treaty, if interpreted "regularly", has a certain meaning that the Indians did and could not envisage, whereas their counterparty was aware of it. The Indians who executed the treaties can not be assumed to have understood the niceties contained in the usage of one legal term over another in a language that is not their own. Such an analysis is, as Belgrave puts it, part of the "paternalistic framework established by colonial powers". ${ }^{65}$

The situation with the Treaty of Waitangi however is entirely different: The authoritative text, if there is such a thing, is not the English but the Māori version. The words used therein do not have a "technical meaning" that is only known to learned lawyers. Rather, their meaning would appear to be clearer to Māori than to Europeans.

\footnotetext{
${ }^{60}$ Treaty of Waitangi Act 1975 s 5(2).

61 Waitangi Tribunal, above n 15, at 47.

${ }^{62}$ At $48-49$.

${ }^{63}$ Waitangi Tribunal, above n 54, at 65.

64 At 65.

${ }^{65}$ Belgrave, above n 29, at 55.
} 
Ambiguities are more likely to be the result of European misperception of the Māori text or of the importance of the English text.

Against this background, applying the contra proferentem rule is, in this author's submission, not the correct approach. It does not seem appropriate for the Tribunal to resolve ambiguities by applying this paternalistic "indulgent rule" (as it refers to it). ${ }^{66}$ Rather, the Tribunal should venture to interpret the Treaty in the Māori version because that is how it was presented, debated and signed.

This paper's fundamental criticism of the application rests on the assumption that it should be the Māori text only that is relevant. Admittedly, this raises the question whether it even makes a difference in the outcome, since the Tribunal already gives precedence to Māori views as embodied in the Māori text, as the contra proferentem rule seems to suggest.

In order to answer this question, this paper will next analyse the Tribunal's application of the contra proferentem rule in the reports published so far

\section{B. A survey of the reports of the Waitangi Tribunal}

As has been shown above, the Tribunal adopted the contra proferentem rule first in the Motunui-Waitara Report. ${ }^{67}$ The Tribunal examined two particular aspects of the second article of the Treaty. The first one was the lack of a specific reference to "fisheries" in the Māori text as opposed to the English text. The Tribunal resolved this issue by relying on the Māori language's “tendency to use words capable of more than one meaning in order to establish the areas of common ground". ${ }^{68}$ It thus considered that the Māori text implied protection for Māori fishing grounds. ${ }^{69}$ The second one was the meaning of the word "rangatiratanga", which went further than "exclusive and undisturbed possession" as in the English text. The Tribunal found the Māori view should prevail because the Māori text was "clearly persuasive" in this regard and because the English text permitted it. ${ }^{70}$

\footnotetext{
${ }^{66}$ See Waitangi Tribunal, above n 15, at 49; Waitangi Tribunal, above n 17, at 128.

${ }^{67}$ Waitangi Tribunal, above n 15, at 49.

68 At 50 .

${ }^{69}$ At 50.

${ }^{70}$ At 51.
} 
In the Manukau Report the Tribunal confirmed to apply "the rules affecting bilingual treaties". ${ }^{71}$ It also reiterated its intention to have regard to the contra proferentem rule as applied by United States courts when interpreting treaties with American Indian tribes. ${ }^{72}$

Notably, the Manukau Report contains the only passage where the Tribunal, although not expressly, makes use of the contra proferentem rule relating to the Treaty in the way the United States courts do so. That is to say, it is the only passage where the Tribunal interprets the English text version in a Māori understanding. It did so in order to determine whether, according to the Treaty, the Māori tribes owned the harbours and foreshore within their tribal areas. At this point, it had already noted that according to the Māori text "the Māori tribes owned the harbours and foreshore within their tribal areas as a matter of Māori customary law", as part of the ownership of all their taonga. ${ }^{73}$ It then compared this finding with the English text: ${ }^{74}$

It is the English text that is not specific. The Crown owns the harbours and foreshores as a matter of the English common law. Its ownership and the rules of common law are presumed to arise by the cession of sovereignty. But in the text the English presumptions of common law are nowhere apparent. They may have been apparent to English lawyers but they would not have been apparent to the Māori signatories had it been the English text that was in fact used and signed. On the evidence before us it can reasonably be assumed that had a Manukau Māori been asked whether by this Treaty his harbour would pass exclusively to the Queen, he would have emphatically replied in the negative.

Therefore, the Tribunal held, the interest of Māori people in the harbour and foreshore areas could not be denied..$^{75}$

In the Orakei Report the Tribunal expressed its belief that where "there is a difference between the two versions considerable weight should be given the Māori text since this is the version assented to by virtually all the Māori signatories." It found this to be consistent with the contra proferentem rule. ${ }^{76}$ It then went on to examine at length the

\footnotetext{
${ }^{71}$ Waitangi Tribunal Manukau Report (Wai 8, 1985) at 65.

72 At 65.

73 At 69.

74 At 69.

75 At 69.

${ }^{76}$ Waitangi Tribunal, above n 17, at 128.
} 
question of the Crown's pre-emption rights as per the second article of the Treaty. ${ }^{77}$ It began its examination by holding: "Under Article 2 of the Treaty the Crown obtained the valuable monopoly right to purchase land from the Māori to the exclusion of all others.",78 This was a surprising point to start with as Ruth Ross had shown in her article that the Māori text was at best unclear about the pre-emption rights, ${ }^{79}$ and the Tribunal had just nine pages earlier reaffirmed its commitment to the contra proferentem rule. ${ }^{80}$ Seven pages later the Tribunal noted: ${ }^{81}$

At the outset it should be said that it is by no means certain that the chiefs understood that Article 2 of the Treaty was intended to give the Crown the sole and exclusive right to purchase Māori land rather than simply the right of first refusal of the land...

It remains unclear why the Tribunal nevertheless did not reconsider its interpretation of the pre-emption rights. Instead, it focussed entirely on the Crown's reciprocal duties. ${ }^{82}$ In this respect, the Tribunal took note of, inter alia, the repeated assurances by Governor Hobson to the chiefs that their lands would be protected and the explanations given to the Māori chiefs of the need for pre-emption on the grounds of preventing land speculation and protecting the Māori. ${ }^{83}$

In the Ngai Tahu Report of 1991 the Tribunal held: ${ }^{84}$

Where there is a difference between the two versions considerable weight should, in our opinion, be given to the Māori text since this is the version assented to by all but a few Māori. This is consistent with the contra proferentum rule that where an ambiguity exists, the provision should be construed against the party which drafted or proposed the provision, in this case the Crown.

When it came to applying the rule, the Tribunal did not go further than repeat findings of the Orakei Report ${ }^{85}$ and the Muriwhenua Fishing Report. ${ }^{86}$

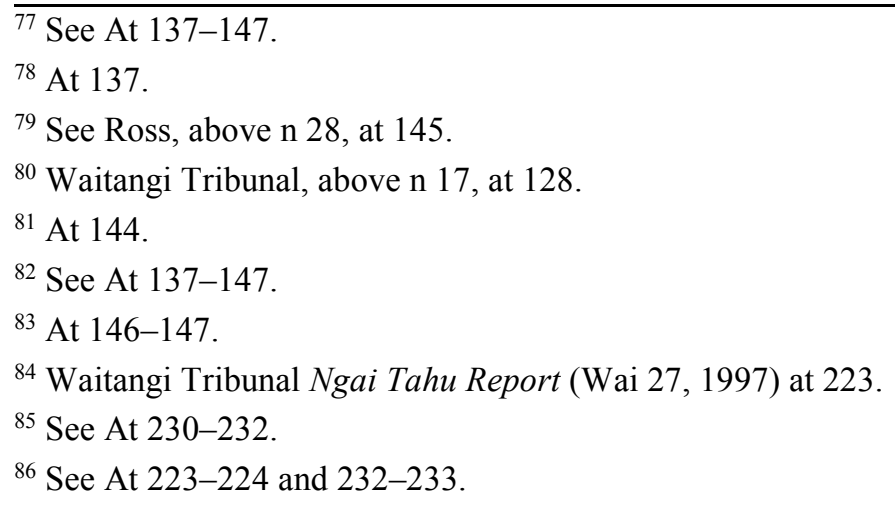


In the Mohaka River Report the Tribunal interpreted a deed of sale of 1851 by which the Ngati Pahauwera had sold the land of the south bank of the Mohaka River. The deed was written in Māori. ${ }^{87}$ The Tribunal drew on the contra proferentem rule when determining whether the bed of the river was sold together with the banks; it concluded that the Ngati Pahauwera's understanding that only the riverbanks were sold ought to prevail. ${ }^{88}$

Making reference to the Mohaka River Report the Tribunal applied the contra proferentem rule in the Ngawha Geothermal Resource Report again in $1993 .{ }^{89}$ The Tribunal was interpreting a deed, which was written in English and contained a summary in Māori, ${ }^{90}$ whereby the Ngapuhi sold to the Crown the Parahirari block, an area of land in the Ngawha geothermal field. The various previous owners had signed the deed from 1886 until $1894 .{ }^{91}$

In the Muriwhenua Land Report of 1997 the Tribunal mentioned the contra proferentem rule, ${ }^{92}$ however the report does not show any signs of the Tribunal giving effect to the rule with regard to the Treaty. ${ }^{93}$ The rule seems to have been applied with regard to the Taemaro claim by the Ngati Kahu o Whangaroa though. This claim was based on pre-Treaty transactions relating to lands east of Mangonui harbour. In this regard, the Tribunal could not find sufficient evidence that the Ngati Kahu ever agreed to the sale of the concerned land: ${ }^{94}$

The lands allocated by Resident Magistrate White were based on an assumption that the pre-Treaty transactions were valid, when the pre-Treaty transactions had not been inquired into as the law required, and when, in terms of the contracts as understood by Māori, the land should have reverted to them once the Europeans involved left the area.

\footnotetext{
${ }^{87}$ See Waitangi Tribunal Mohaka River Report (Wai 119, 1992) at 27-34.

${ }^{88}$ At 34.

${ }^{89}$ Waitangi Tribunal Ngawha Geothermal Resource Report (Wai 304, 1993) at 61-62.

${ }^{90}$ At 59.

${ }^{91}$ At 44.

92 Waitangi Tribunal Muriwhenua Land Report (Wai 45, 1997) at 387.

93 See At 385-391.

${ }^{94}$ See At 403 (regarding the Taemaro claim).
} 
The rule then vanished from Tribunal reports until it reappeared in 2004 in the Mohaka ki Ahuriri Report, where the Tribunal referred to its contemplations in the Orakei Report. ${ }^{95}$

The second time the Tribunal visibly applied the rule when interpreting the Treaty (as opposed to the deeds that were the subject matter in the Mohaka River Report and the Ngawha Geothermal Resource Report) came in 2010, in the Tauranga Moana Report ${ }^{96}$. The Tribunal first made an introductory remark on "the widely accepted principle of contra proferentem" as it had done many times before. ${ }^{97}$ It then relied on the rule when examining the Crown's policy to individualise the Tauranga Māori tenure of land, freed of communal control, starting from 1886. It noted: ${ }^{98}$

While article 2 of the treaty, in the English text, guaranteed 'to the Chiefs and tribes of New Zealand and to the respective families and individuals thereof' ongoing ownership of all properties they 'collectively or individually' possessed, there is no mention of individuals in the Māori text; rather, the Māori text mentions only 'nga rangatira me nga hapu o Nu tireni' (the chiefs and hapū of New Zealand).

The Tribunal observed that while the Crown's action was arguably not in breach of the Treaty according to the English text, the same could not be said of the Māori text. It then held: 99

In line with the contra proferentem rule, where any ambiguity in a contract is to be interpreted against the interests of the drafter, we are of the view that the Māori version of article 2 should take precedence.

Most recently, in the 2013 Te Kähui Maunga Report ${ }^{100}$, the Tribunal again made use of the contra proferentem rule. As in the Mohaka River Report and the Ngawha Geothermal Resource Report it applied the rule when interpreting a deed of sale. ${ }^{101}$ As in the Ngawha Geothermal Resource Report the deed was written in English and contained a summary in Māori (“Clear Statement in the Māori Language"). ${ }^{102}$

\footnotetext{
${ }_{95}^{5}$ Waitangi Tribunal Mohaka ki Ahuriri Report (Wai 201, 2004) at 18.

${ }^{96}$ Waitangi Tribunal Tauranga Moana 1886-2006: Report on the Post-Raupatu Claims (Wai 215, 2010).

${ }^{97}$ At 18.

${ }^{98}$ At 147.

${ }^{99}$ At 148.

${ }^{100}$ Waitangi Tribunal Te Kāhui Maunga: The National Park District Inquiry Report (Wai 1130, 2013).

${ }^{101}$ At 502-505.

${ }^{102}$ At 503.
} 


\section{Analysis of the application of the contra proferentem rule by the Waitangi Tribunal}

\section{The different methods of applying the rule}

The above Tribunal's reports, where the rule was applied, can be divided into four groups, based on the different effect the Tribunal gave to the rule: (a) coordinated application of the two texts; (b) precedence of the Māori text; (c) strict application of the contra proferentem rule and (d) contextualised interpretation of the Treaty.

\section{a) Coordinated application}

The first example of the Tribunal's application of the rule is found in the MotunuiWaitara Report. In this report, the Tribunal sought to reconcile the English and the Māori text: Noting that the Māori "rangatiratanga" went further than the English "full exclusive and undisturbed possession" it still emphasised that the latter permitted to adopt the Māori view. At the time, the Tribunal ostensibly avoided to give preference to one of the texts and instead aimed at a coordinated application of both texts.

\section{b) Precedence of the Māori text}

One of the most recent examples of the Tribunal's application of the rule is the Tauranga Moana Report, where the Tribunal used it to clarify an ambiguity arising from differences between the English and the Māori text. The Tribunal held plainly that the Māori version should take precedence.

This can be seen as an advancement of the Tribunal's interpretation of the Treaty in the Motunui-Waitara Report, where it aimed more at reconciling the English and the Māori text. A further development could be found in the Orakei Report (and subsequently in the Ngai Tahu Report) where the Tribunal considered that "considerable weight" should be given to the Māori text in case of a difference between the two texts. This was a distinctly stronger statement than in the Motunui-Waitara Report, but it needed yet another step of development to reach the Tribunal's avowal of precedence of the Māori text. It remains to be seen if future reports will follow the rule stated in the Tauranga Moana Report or return to statements made in the earlier reports. 


\section{c) Application sensu stricto}

In a number of reports, the Tribunal applied the contra proferentem rule sensu stricto, that is to say it attempted to determine the Māori understanding of unfamiliar terms contained in a legal document.

The first example of this form of the rule's application can be found in the Manukau Report, where the Tribunal held that Māori could not be assumed to have recognized "the English presumptions of common law" that "may have been apparent to English lawyers". This is the only example of a true application of the contra proferentem rule when interpreting the Treaty that can be found in the reports of the Tribunal.

Incidentally, such an application of the rule was fitting: Claimants in the Manukau Report were the Waikato-Tainui group of tribes, ${ }^{103}$ and it was the Waikato chiefs that had signed the English text of the Treaty. ${ }^{104}$ However, nothing in the Report indicates that the Tribunal based its considerations on these special circumstances. Rather, the wording of the Tribunal ("[the English presumptions of common law] would not have been apparent to the Māori signatories had it been the English text that was in fact used and signed"105) suggests that it made this point only for the sake of the argument.

The other reports containing an application sensu stricto are the Mohaka River Report, the Ngawha Geothermal Resource Report, the Muriwhenua Land Report of and the Te Kähui Maunga Report. These have in common that the rule was not applied to the Treaty but to deeds of sale, which were for the most part (the exception being the Mohaka River Report) written and signed in English. Additionally, all these transactions were made after the Treaty was signed. Therefore, the English common law presumptions referred to by the Tribunal in the Manukau Report would have applied to them. Thus, it was appropriate for the Tribunal to interpret these deeds of sale contra proferentem.

\section{d) Contextualised interpretation}

Two reports attempted to determine the Māori understanding of the Treaty by looking at the oral context of the signing. Those are the Orakei Report and the Muriwhenua Land

\footnotetext{
103 See Waitangi Tribunal, above n 54, at 1.

${ }^{104}$ See above IV.C.

${ }^{105}$ Waitangi Tribunal, above n 54, at 69.
} 
Report. In the Orakei Report the Tribunal asked what explanations of the pre-emptive provisions Captain Hobson and his representatives gave to the Māori chiefs. ${ }^{106}$ The disillusioning answer turned out to be that there was "surprisingly little on record as to what explanation was given to the Māori by way of justification for the pre-emptive provision in Article 2." ${ }^{\prime 107}$

In the Muriwhenua Land Report the Tribunal was presented the question whether, according to the Treaty, the pre-Treaty land transactions had to be judged by Māori customary law. The Tribunal noted that the expectations of the Māori and the British diverged in this respect, when the Treaty was signed. The Tribunal found in favour of the Māori because, as Belgrave summarized, "Māori law prevailed until 1840 and under the treaty was to be protected and observed after 1840". ${ }^{108}$ The Tribunal's considerations with regard to the oral context of the Treaty signings will be dealt with below. ${ }^{109}$

\section{Conclusion}

The point of conducting the above analysis of tribunal reports was to determine if there is a difference in the outcome between a true interpretation of the Māori text and the application of the contra proferentem rule by the Tribunal.

The answer, as can be seen from the above analysis of the reports, must be "yes": There is a difference. Understandably_-given its task to "have regard to the 2 texts of the Treaty"- the Tribunal was reluctant to give clear precedence to the Māori text over the English text. Rather, the Tribunal usually aims to reconcile the two texts. Thus, if the Māori text is ambiguous, the Tribunal will be tempted to choose a construction that is compatible with the English text. And even if it does not, its interpretation of the Māori text will, to some extent, be influenced by the English text. Therefore, the question whether the Tribunal's application of the contra proferentem rule is historically justified or, as this paper argues, the only relevant text, for the most part, is the Māori text, is not purely academic.

\footnotetext{
${ }^{106}$ Waitangi Tribunal, above n 17, at 144.

107 At 145.

${ }^{108}$ Michael Belgrave "Looking Forward” (2006) 40 NZJH 230 at 240.

109 See below VI.
} 


\section{The Treaty and Māori oral culture}

The Tribunal should not only be criticised for looking too much at the English text but for looking too much at the text at all. While the Tribunal attempts to give voice to the Māori understanding of the Treaty by using the contra proferentem rule, it is still relying strongly on the written texts. Michael Belgrave criticised this in 2005, arguing that the signing of the Treaty should be looked at as an oral event rather than a written document. ${ }^{110} \mathrm{He}$ pointed out that the discussion of Māori understanding of the Treaty focuses only on their understanding of the wording of the clauses in the Treaty and not on the context that is made up of Māori values and world-view. ${ }^{111}$

In what has been referred to as "[t]he one serious attempt to look at the signing of the Treaty of Waitangi as an oral event"112, Donald Francis McKenzie pointed out the oralaural character of the Treaty meeting for the Māori: First, he argued, given that the Treaty was read out in Māori it was not received as a written document but as an oral statement. ${ }^{113}$ Second, the Māori mode of dealing with the Treaty, their "very form of public discourse and decision-making" was purely oral. It resulted in the consensus, not in the written text of the Treaty. ${ }^{114}$ McKenzie thought it to be "inconceivable" that the missionaries' explanations to the Māori were a mere monologue without response. Many chiefs would, he suspected, have made oral conditions to the text read out to them before signing the Treaty. ${ }^{115} \mathrm{He}$ concluded that for the Māori "the 'text' was the consensus arrived at through discussion, something much more comprehensive and open than the base document or any one of its extant versions." 116

The Tribunal is not ignorant of the importance of the context of the signings. In the Orakei Report it took note of the Canadian case $R v$ Taylor ${ }^{117}$, where the Ontario Court of

\footnotetext{
${ }^{110}$ Belgrave, above n 29, at 54.

${ }^{111}$ At 54-55.

112 At 54 .

113 DF McKenzie Oral culture, literacy \& print in early New Zealand (Victoria University Press, Wellington, 1985) at 35.

${ }^{114}$ At 40.

${ }^{115}$ At 40 .

${ }^{116}$ At 44.

${ }^{117} R v$ Taylor, above $\mathrm{n} 8$.
} 
Appeal had considered that the surrounding circumstances needed to be taken into regard in the interpretation of treaties. ${ }^{118}$ The Tribunal also referred to the New Zealand Court of Appeal's decision in New Zealand Maori Council v Attorney-General, where the Court observed that, due to the emphasis on oral discussion and decision making and limited literacy, the Māori understanding would have depended on "what explanations were given to the particular signatories and their appreciation of the concepts involved."119

The Tribunal is of course equally aware that Māori culture at the time was predominantly oral: In the Ngai Tahu Report it held that the Māori language had been a purely oral one until the early 1820 s. $^{120}$ It was less than twenty years before the signing of the treaty that for the first time the Māori language was reduced to written form. ${ }^{121}$ Since the early missionaries performed this task, ${ }^{122}$ the earliest printed Māori consists of passages of the Bible. ${ }^{123}$ When Williams later drafted the Māori text of the Treaty, he would borrow some of the key words from the Bible: "Kawanatanga" (for "sovereignty" in the Treaty text) was derived from "kawana", which, as a transliteration of "governor", had been in use both for Australian Governors and for Pontius Pilate; "rangatiratanga" (for "full exclusive and undisturbed possession" in the Treaty text) had been used for the kingdom of God. ${ }^{124}$

While the 1830 s, largely due to publications of the missionaries, had seen a great boom in Māori literacy, ${ }^{125}$ the Treaty was aptly described by the Tribunal in the Te Roroa Report as an agreement between two parties, "one of which had an oral culture, the other a literate culture." ${ }^{126}$ As an oral arrangement, the Tribunal further observed, the Treaty

\footnotetext{
${ }^{118}$ Waitangi Tribunal, above n 17, at 129.

${ }^{119}$ New Zealand Maori Council v Attorney-General [1987] NZCA 60, [1987] 1 NZLR 641 (NZCA) at 671 per Richardson J.

120 Waitangi Tribunal, above n 67, at 221.

121 At 221.

122 At 221.

${ }^{123}$ Lyndsay Head "The Pursuit of Modernity in Maori Society: The conceptual bases of citizenship in the early colonial period" in Andrew Sharp and Paul G McHugh (eds) Histories, Power and Loss: Uses of the Past - A New Zealand Commentary (Bridget Williams Books, Wellington, 2001) 97 at 104.

124 Ross, above n 28, at 139-143.

${ }^{125}$ At 137.

${ }^{126}$ Waitangi Tribunal Te Roroa Report (Wai 38, 1992) at 30.
} 
could only be understood in the context of the debate among Māori that preceded the signing. ${ }^{127}$

In the Motunui-Waitara Report, the Tribunal took note of a tendency of the Māori language to use ambiguous words in order to establish the areas of common ground, rather than to emphasise differences, in order to achieve a degree of consensus or to enable a dialogue. ${ }^{128}$ It summarized that from a Māori perspective the Treaty's spirit is "something more than a literal construction of the actual words used can provide" and "transcends the sum total of its component written words". ${ }^{129}$ As the Tribunal put it in the Muriwhenua Land Report, "in forming contracts, Māori looked not to the heart of the terms but to the heart of the person making them."130

The above survey of Tribunal reports reveals that only twice did the Tribunal seriously attempt to contextualise the Treaty signings: in the Orakei Report and the Muriwhenua Land Report. ${ }^{131}$ The Orakei Tribunal however, confining itself to oral explanations by Crown representatives as to the pre-emptive provisions in Article 2, only came to realise that there was little on record in this regard. ${ }^{132}$

The Muriwhenua Land Report was where the Tribunal, according to Belgrave, "came closest to unpacking the Treaty meetings at Waitangi and Kaitaia as hui". 133 "Hui" is a general term in Māori for any kind of meeting, but is mostly used for ceremonial gathering on a marae (a local ceremonial centre $\left.{ }^{134}\right) .{ }^{135}$

Discussing Māori expectations with regard to the Treaty, the Tribunal took note of the record of Treaty debates at Waitangi on 6 February 1840, at Mangungu on 11 February 1840 and at Kaitaia on 28 April $1840 .{ }^{136}$ It went on to hold that, while the record was

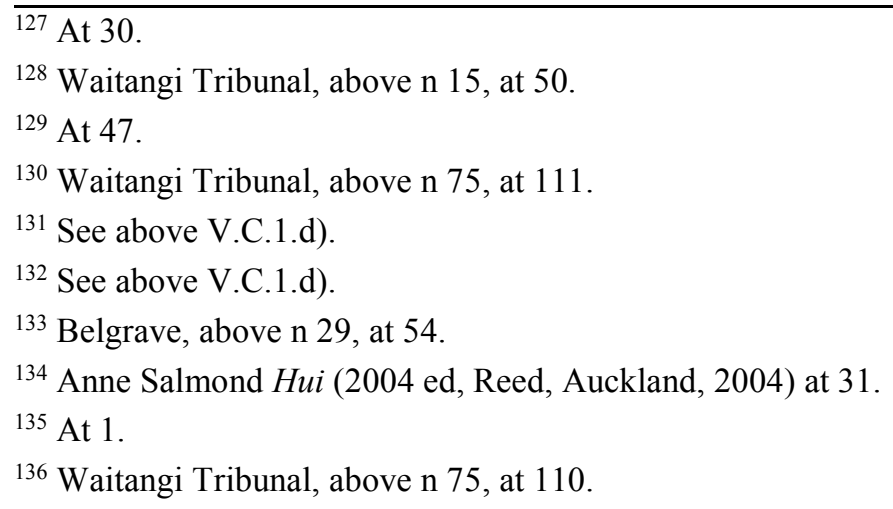


important, it had to be treated with caution, as it did not contain the debate in Māori but only an English translation thereof. ${ }^{137}$ Accordingly, it might be more accurate a testimony of the translator's understanding than of Māori intentions. ${ }^{138}$

The Tribunal observed that the "Māori contribution to the making of the Treaty reflects their debating modes and the customs that gave their order of speaking". ${ }^{139}$ The very fact of having a debate gave weight to a matter, allowed to frame the issues and "[left] stories to memorialise the event". ${ }^{140}$ The Tribunal noted how the Māori by gathering at Waitangi in such large numbers honoured the friendly relationship with the missionaries. While the Governor had unfortunately failed to organise a feast at Waitangi, large feasts were held at Mangungu and Kaitaia. ${ }^{141}$ The Tribunal recognised this to be "more important for establishing a relationship than any contractual terms". It noted how the Māori chief Panakareao would later remind officials "of the feast, not the Treaty, when describing the responsibilities of each to the other". ${ }^{142}$

As the Law Commission held in a 2001 study paper, "in traditional Māori thinking relationships are everything". ${ }^{143}$ Agreements were not merely embedded in the overarching relationship but strengthened and developed it. Similarly, the Tribunal identified the underlying purpose of gift exchange as securing lasting relationships. ${ }^{144}$

Turning to the debate, the Tribunal noted in terms of the order of speakers that it was usual for the main leader to be the last to speak. This enabled chiefs to sense when a consensus was reached and declare it. All this helped achieve lasting decisions. ${ }^{145}$

These observations allowed the Tribunal to put much weight on the closing address by Chief Panakareao at Kaitaia. And when analysing said closing address, the Tribunal focussed mainly on the famous quote: "The shadow of the land goes to the Queen but the

\footnotetext{
137 At 110 .

138 At 112 .

139 At 110 .

140 At 111 .

141 At $110-111$.

142 At 111.

${ }^{143}$ Law Commission Māori Custom and Values in New Zealand (NZLC SP9, 2001) at [130].

144 Waitangi Tribunal, above n 75, at 28.

${ }^{145}$ At 112.
} 
substance remains with us." While its analysis also took into account quotes from another Māori leader and the Governor's response, the Tribunal did not deem it necessary to give full account of the debates. ${ }^{146}$

The Tribunal's observations with regard to the oratory part of a hui (the whaikorero) are, for the most part, to the point. In many areas, the position of honour is that of the last speaker. It is for him to round off the discussion and give the definitive speech. ${ }^{147}$ This, however, does not hold true for all of New Zealand: In the East Coast area it is the most important elder who speaks first. ${ }^{148}$ It is also possible that the most knowledgeable elder of the hosting party chooses to speak first in order to identify the visitors. ${ }^{149}$

The ritual of whaikorero takes up a considerable amount of time, and the audience has to listen to one speaker after another for long hours. People tend to get bored and thus easily distracted. It is not uncommon that after some time only the speakers listen to each other, while the rest of the audience divert themselves. An extraordinary speech on the other hand stands out and naturally draws the attention of the audience. ${ }^{150}$ Thus, a speaker's influence in the debate should be judged not only by the order of speaking but also taking into account the reaction of the audience as well as that of the subsequent speakers.

The discussion of the debate in the Muriwhenua Land Report is rather brief and, as mentioned above, largely limited to one line by one Māori chief. In that sense, the Tribunal seems to have fallen short of contextualising the Treaty signing. The subsequent enumeration of Māori perspectives however reveals that the Tribunal did in fact draw from the entire debate and the cultural context. This is indicated, for instance, by the Tribunal's insights that Māori expected to be equal to the Governor (from the "persistent metaphor ... that the Governor should not be up and Māori down" ${ }^{151}$ ) and that the trust

\footnotetext{
146 At $112-113$.

147 Salmond, above n 134, at 153.

148 At 153.

149 At 153.

150 At 165.

${ }^{151}$ Waitangi Tribunal, above n 75, at 114 .
} 
and affection to the Governor displayed by Māori were "essential ingredients to forming a lasting relationship". ${ }^{152}$

No other report seems to have seriously examined the Treaty signings as oral events. This appears to be especially true for the many later signings following the meeting at Waitangi. These varied greatly both in the number of signatures by chiefs and in the reception of the Treaty that was displayed: Hokianga, for instance, saw the gathering of around 500 chiefs of different degrees who were well prepared for the debate. The Treaty was discussed controversially and promises given at the meeting were important to secure the signatures at that meeting. ${ }^{153}$ On the other hand, the missionaries asked to collect signatures in the Arawa-Ngāti Tūwharetoa districts were entirely unsuccessful. These chiefs declined to sign and the Treaty sheet would disappear. ${ }^{154}$ In contrast, the Māori of Stewart Island were not even invited to sign the Treaty. ${ }^{155}$ In turn, the chiefs who signed the English text at Waikato-Heads appear to have done so on missionary advice; there is no record of an explanation of the Treaty at the meeting. ${ }^{156}$ Some iwi and indeed entire regions (such as the Urewera region) until now never adhered to the Treaty. ${ }^{157}$

For the most part, these different perceptions of the Treaty were not given attention by the Tribunal. The circumstances of the signings were in most reports not investigated and the cultural context of the gatherings as hui was described in only one report. In this regard, the Tribunal has unfortunately not managed to situate the Treaty in its oral and Māori context.

\section{Conclusions}

A survey of the earlier Tribunal reports reveals some shortcomings of the Tribunal's approach in interpreting the Treaty. While it is not ignored that the Treaty is in its essence a document in Te Reo Māori, this understanding has hardly informed the Tribunal's 
approach in ascertaining the meaning of the Treaty. Certainly, the Tribunal is right in looking at the Treaty from a Māori perspective, yet this approach should not be based on the contra proferentem rule as that rule falsely presumes a Māori failure to understand the English text as the "true" content of the treaty.

Moreover, the Tribunal's approach is thus locked into the frame of the two texts and their differences. As this paper has shown, and perhaps counter-intuitively, the contra proferentem rule places too much weight on the English text.

However, it is the Māori text that should be taken as the more authentic version. The written text, though, was in a predominantly oral culture merely the starting point of the Treaty debate, in which a consensus was reached. Unfortunately, for the most part-with the notable exception of the Muriwhenua Land Report - the Tribunal has not given adequate attention to the context of the Treaty signings, that is the Treaty debates in meetings. This, however, is what the Treaty for many of the Māori signatories was: The consensus reached in the public debate during a festive gathering. 


\title{
BIBLIOGRAPHY
}

\section{PRIMARY SOURCES}

\section{A Cases}

1 New Zealand

New Zealand Maori Council v Attorney-General [1987] NZCA 60, [1987] 1 NZLR 641 (NZCA).

Waitangi Tribunal Motunui-Waitara Report (Wai 6, 1983).

Waitangi Tribunal Manukau Report (Wai 8, 1985).

Waitangi Tribunal Orakei Report (Wai 9, 1987).

Waitangi Tribunal Mohaka River Report (Wai 119, 1992).

Waitangi Tribunal Te Roroa Report (Wai 38, 1992).

Waitangi Tribunal Ngawha Geothermal Resource Report (Wai 304, 1993).

Waitangi Tribunal Ngai Tahu Report (Wai 27, 1997).

Waitangi Tribunal Muriwhenua Land Report (Wai 45, 1997).

Waitangi Tribunal Mohaka ki Ahuriri Report (Wai 201, 2004).

Waitangi Tribunal Tauranga Moana 1886-2006: Report on the Post-Raupatu Claims (Wai 215, 2010).

Waitangi Tribunal Te Kāhui Maunga: The National Park District Inquiry Report (Wai 1130, 2013).

\section{Canada}

$R v$ White [1964] CarswellBC 212 (BC CA).

$R v$ Taylor [1981] CarswellOnt 641 (Ont CA).

\author{
3 United States of America \\ Worcester v State of Georgia [1832] 31 US 515. \\ Jones v Meehan [1899] 175 US 1.
}

\section{B Statutes}

Treaty of Waitangi Act 1975. 
SECONDARY SOURCES

\section{A Books}

Belgrave, Michael Historical frictions (Auckland University Press, Auckland, 2005).

Biggs, Bruce "Humpty-Dumpty and the Treaty of Waitangi" in IH Kawharu (ed) Waitangi: Māori and Pākehā Perspectives of the Treaty of Waitangi (Oxford University Press, Auckland, 1989) 300.

Buick, T Lindsay The Treaty of Waitangi (2nd ed, Thomas Avery, New Plymouth, 1933). Byrnes, Giselle The Waitangi Tribunal and New Zealand history (Oxford University Press, Melbourne, 2004).

Colenso, W The authentic and genuine history of the signing of the Treaty of Waitangi, New Zealand, February 5 and 6, 1840; being a faithful and circumstantial, though brief, narration of events which happened on that memorable occasion, with copies of the Treaty in English and Māori, and of the three early proclamations respecting the founding of the colony (Capper Press, Christchurch, 1971).

Deloria, Vine and DeMallie, Raymond J (eds) Documents of American Indian diplomacy (University of Oklahoma Press, Norman, 1999).

Goddard, Ives "Introduction" in Ives Goddard (ed) Handbook of North American Indians (Smithsonian Institution, Washington, 1996) 1.

Head, Lyndsay "The Pursuit of Modernity in Maori Society: The conceptual bases of citizenship in the early colonial period" in Andrew Sharp and Paul G McHugh (eds) Histories, Power and Loss: Uses of the Past - A New Zealand Commentary (Bridget Williams Books, Wellington, 2001) 97.

Johansen, Bruce E (ed) Enduring Legacies: Native American Treaties and Contemporary Controversies (Praeger, Westport, Conn, 2004).

McKenzie, DF Oral culture, literacy \& print in early New Zealand (Victoria University Press, Wellington, 1985).

McNair, Arnold Duncan The Law of Treaties (Clarendon, Oxford, 1961).

Orange, Claudia The Treaty of Waitangi (2nd ed, Bridget Williams Books, Wellington, 2011).

Salmond, Anne Hui (2004 ed, Reed, Auckland, 2004). 
Sutton, Mark Q An Introduction to Native North America (Allyn and Bacon, Boston, 1999).

\section{B Journal Articles}

Belgrave, Michael "Looking Forward” (2006) 40 NZJH 230.

Boast, RP "Recognising Multi-textualism: Rethinking New Zealand's Legal History" (2006) 37 VUWLR 547.

McAloon, Jim "By Which Standards? History and the Waitangi Tribunal" (2006) 40 NZJH 194.

Ross, Ruth “Te Tiriti o Waitangi: Texts and Translations” (1972) 6 NZJH 129.

Spirling, Arthur "US Treaty Making with American Indians: Institutional Change and Relative Power, 1784-1911”56 AJPS 84.

\section{Reports}

Law Commission Māori Custom and Values in New Zealand (NZLC SP9, 2001). 